\title{
Stabilizing the Korea Peninsula Through Economic Cooperation
}

\author{
Liu Qun
}

Published online: 15 October 2013

(C) CEEUN 2013

\begin{abstract}
Because of the complex historical backgrounds, stabilizing the Korea Peninsula will be a long-term process. In the face of enormous pressure from the powerful ROK-US Alliance and South Korea's advanced economic development, North Korea will continue to pursue its military-first policy in the foreseeable future and is unwilling to fully open its doors. As a junction of Eurasia, North Korea has a unique geopolitical advantage. When it starts conduct an economic open door policy it would achieve great economic performance in future. Nowadays although North Korean officials do not recognize the reform and opening up policy, the fact is that North Korea has begun exploring the road to economic development. The promotion of peace and further development through economic cooperation is a more realistic and feasible means of bringing about effective resolutions. Economic cooperation on the Korean Peninsula will benefit the economic development of Northeast Asia and the rest of the world, But North Korea cannot conduct fundamental economic development without an improved external environment. Promoting economic cooperation should not only the core task of North Korea, but also the common focus of interested countries. Taking steps to improve North-South bilateral relations and avoiding military conflict are ongoing short-term concerns. In future, the international community also needs to improve economic cooperation with North Korea.
\end{abstract}

Keywords Korea $\cdot$ Northeast Asia $\cdot$ Reunification $\cdot$ Economic Cooperation

JEL classification F02-04-053

The author wishes to thank Mr. Ross Tokola of the Asan Institute for Policy Studies for assisting in the preparation of this paper for presentation and publication.

L. Qun (凶)

National Defense University PLA China, Beijing, China

e-mail: Liu7384@gmail.com 


\section{Introduction}

It has been 60 years since the Korean War Armistice Agreement was signed at Panmunjom on July 27, 1953. The two Koreas have since had a long history of military confrontation. Although there is a sense in both Koreas that future reunification is inevitable, North and South Korea are more economically, politically and socially different today than they were in the past. During the last few years, both Koreas have strengthened their armed forces. The best situation that can be hoped for is to avoid the violence that often springs from confrontation, and continue to seek ways to resolve confrontation before the point of violence is reached. Recent regional leadership changes have made the future of the Korean peninsula more uncertain. Over the years, the Korean Peninsula has become a barometer of peace and security in Northeast Asia. International society has made great efforts in trying to settle the nuclear issues on the Korea Peninsula, but the results of these efforts are not obvious and the situation in recent years has deteriorated. This paper shall argue that to resolve the security issues faced by Korea and Northeast Asia, greater focus on economic cooperation through carefully planned step-by-step processes offers the best chance for political reconciliation.

\section{The Root of the Korean Peninsula Security Issues}

Nowadays, North Korea faces serious challenges in national defense and in its economy. Korea Peninsula security issues can only be resolved after North Korea finds a way to develop its economy.

The Main Challenge to Peace and Development on the Korean Peninsula

In the long-term the key issue for the Korean Peninsula is the reunification of the two Koreas. In the short-term, it is to denuclearize the Korean Peninsula. Since the division of Korea, more than half a century has elapsed. From the early days of the division, the two Koreas have both given priority to reunification. Most Koreans believe that North and South Korea moving towards the goal of reunification is only a matter of time. However, for the past 60 years, inter-Korean relations are still in a repetitive cycle of reconciliation, improvement, confrontation and exacerbation. Though both sides want to reunify, the question is how to address disagreements between the two sides on how reunification is to be accomplished.

The North Korean nuclear issue is a concentrated focus of Northeast Asia's international relations. According to the International Atomic Energy Agency (IAEA), North Korea has been developing its nuclear capabilities for a long time. North Korea began nuclear technology research in the late 1950s. In the mid-1960s, North Korea created the Yongbyon Nuclear Research Base, and trained a large number of nuclear technical personnel. North Korea has been attempting to obtain nuclear weapons since the late 1970s. By 1994, with the diplomatic pressure on North Korea, North Korea signed an agreement to dismantle its plutonium program. South Korea and the United States in turn agreed to provide light water reactors and 
fuel oil to North Korea. However, the dismantling process was not successful. On October 9, 2006, the North Korean government announced it had successfully conducted a nuclear test. North Korea made another announced that it had conducted a nuclear test in April 2009. Since then, North Korea and the international community appear to have entered into long-term stagnation on the nuclear issue. The negotiation process has taken many twists and turns. The difference is around the question of whether North Korea abandoning its nuclear program would lead to peace or whether a peace agreement would lead to North Korea dismantling its nuclear programs. The international community adopted several approaches in attempting to keep North Korea from becoming a nuclear country. These efforts fell apart when North Korea walked away from negotiations and refused to abandon its uranium enrichment program. The issue is further complicated by the differing stances among Six-Party Talks members.

The Reason the DPRK Seeks to Develop Nuclear Weapons

North Korea's nuclear tests received unanimous opposition from the international community. Considering North Korea's economic situation, why it does not channel its resources into economic development and waste so much of its resources on nuclear development instead? Analyses of North Koreas situation indicate that the main purpose of North Korean's nuclear tests were not to give offence but something else.

\section{Raising its International Status and Negotiation Bargaining Power}

North Korea's intention in developing its nuclear weapons is to seek to an equal footing with the United States, Japan, and South Korea during negotiations, increase its own negotiating capabilities, and enhance its international status. For North Korea, nuclear weapons are a kind of political weapon. Since the end of the Second World War, although the Cold War arms race intensified, nuclear weapons were never put into military application. In terms of quantity and quality, North Korea's nuclear weapons fall far behind the capabilities of more advanced countries, such as the United States. North Korea's nuclear weapons programs are mere policy instruments with which it desires to secure its fundamental national interests, such as survival, prosperity, and even prestige. Historically, North Korea has used the nuclear card to bring the United States to the negotiation table. North Korea has stated that the quid pro quo for denuclearization is none other than the establishment of a peace regime on the Korean Peninsula (Nandu.com 2010). However, considering the magnitude of distrust and the history of nuclear negotiations in the past, we can only solve this problem through a long process of dialogue and negotiation.

\section{Access to Military Deterrent Capability}

One of the purposes of North Korea developing its nuclear technology and nuclear weapons is for North Korea to possess a means of deterrence to compensate for its 
disadvantages in conventional weapons. North Korea adopted its military-first policy based on its security concerns. This is especially the case since the 1970s, when South Korea's economy gradually began to take off, both in industrial manufacturing and high technology. The widening of the gap between North Korea and South Korea also came with a widening in the gap between the two sides' weaponry. Once one also takes into account the existence of the military alliance between South Korea and the United States, it might appear quite understandable for North Korea to be concerned for its national security. Because North Korea did not have any advantages in terms of its conventional capabilities, the only way for North Korea to strengthen its confidence in its self-defense was to develop nuclear weapons.

Another reason is that several recent high-tech wars, such as the Gulf War, the Kosovo War and the wars in Afghanistan, Iraq, and Libya, have caused government officials in North Korea to feel insecure. This feeling was bolstered by US President George W. Bush naming North Korea part of an "Axis of Evil" following the September 11, 2001 terrorist attacks. Even though US officials stated that the United States was not planning any immediate military action toward North Korea, but the Bush administration's doctrine of pre-emptive military action worried the North Korean regime. These reasons contributed to North Korea perceiving nuclear weapons as military deterrents.

\section{Improving Domestic Confidence and Stability}

Acquiring nuclear weapons has always been a fast-track means for a nation to enhance its military strength. Since the collapse of the Soviet Union, attempts at North Korean economic development has faced tremendous challenges. North Korea's efforts at international economic cooperation sharply dropped down after 1991. Poor economic performance and a series of famines affected, to a certain extent, the domestic political stability of the North Korean leadership. The North Korea government had to reduce its public food distribution because of food shortages. This led to North Koreans needing to find food on their own, including by illegally conducting business to earn the money necessary to buy food on the black market. Under these circumstances, many North Koreans began illegally crossing the border to China to find food. Approximately 100,000 to 300,000 North Koreans are currently residing in China (Jinwook 2006). The dire conditions within North Korea led to fragility in North Korea's social stability and the weakening of social controls.

Nuclear weapons are considered symbols of the national strength and international status. In history, nuclear weapons have played a very important role in improving a nation's global status. North Korean leadership might therefore have assumed that North Korea's confidence could be restored through nuclear weapons development. North Korea possessing nuclear weapons is a means of achieving North Korea's national goal of becoming a "strong and prosperous nation", a goal which is undoubtedly encouraged among the North Korean people to foster popular confidence and cohesion. 
Eliminating the Roots of North Korea's Striving for Nuclear Weapons

North Korea's underdeveloped economy is the root of North Korea's difficulties. Poor economic performance brings poverty, frustration, and doubt to the public, thereby diminishing social cohesion. Furthermore, poor economic performance will hinder North Korea's modernization of its national defense, leaving the nation with outdated weapons and inadequately maintained equipment. Under these circumstances, nuclear development is expected to overcome North Korea's challenges not only in economic areas but North Korea's social and political conditions. In order to eliminate the root causes of North Korea's striving for nuclear weapons development, it is necessary to find a solution that would facilitate North Korea regaining confidence in its economic development.

\section{Economic Benefits to National Defense}

In fact, North Korea faces two main sets of challenges. The first main set of challenges involves security threats from the outside. The second main set of challenges is North Korea's economic plight, which it has been suffering from for a long time. Even if nuclear weapons can reduce North Korean concerns about military-security issues, North Korea still faces the challenge of poor internal economic performance. Security and economic problems are both deeply interconnected. The Korean Central News Agency published an editorial that made the following argument: North Korea's striving to acquire nuclear weapons is not a threat to other countries. It is intended to improve the Korean People's Army's deterrence capabilities. With nuclear weapons, we can reduce the cost of conventional weapons, save financial resources, and put these resources into civilian projects to develop our national economy in order to improve our people's standard of living. Such explanations from North Korea have not been accepted by the international community, as demonstrated by the Russia newspaper Izvestia, which stated that Pyongyang's new reason for possessing nuclear weapons shocked the world. Nevertheless, it is reasonable to accept the argument that nuclear weapons are more cost effective as deterrents compared to the expense of developing and maintaining conventional weapons.

\section{To Improve the International Economic Environment}

For North Korea, creating a favorable environment for international economic development is very important. Security is the precondition for its economic development. Under conditions of insecurity, North Korea is unable to focus on economic development. Under these conditions, the majority of North Korea's resources will continue to be channeled into defense-building in order to meet its perceived survival needs. To focus on conducting economic reforms, the North Korean leadership has traditionally believed that it must first stabilize its security. The North Korean leadership has considered the attitude of the United States as crucial to this end. It believes that the only way to improve its international security is to have direct dialogues with the United States. North Korea has therefore made 
use of nuclear tests as a bargaining tool to attempt to glean compromises and security guarantees from the United States. However, when North Korea makes use of its nuclear weapons for leverage in political bargaining, it makes an already fragile situation on the Korean Peninsula even more complex and uncertain.

\section{Economic Benefits from International Society}

Historically, North Korea was not a self-enclosed country. In the years following its founding as a state, North Korea joined in the socialist camp and traded with socialist countries. But in 1991, with the collapse of the Soviet Union, the socialist camp disintegrated. This event was a devastating shock to North Korea. After 1994, there were successive years of major natural disasters that further compounded North Korea's difficulties.

Aside from purposes of security, although North Korea denied take the nuclear deterrent in exchange for economic aid (Chao et al. 2006). But North Korea can also expect considerable sums in financial compensation for abandonment of its nuclear weapons program. For example, the Clinton administration gave North Korea food and energy, and took a relatively moderate stance vis-à-vis North Korea. But when the Bush administration came into power, the US government adopted a hostile policy toward North Korea. Soon afterwards, North Korea restarted its nuclear program.

There is another economic reason for North Korea developing its nuclear capabilities. North Korea suffers a shortage of electricity. Nuclear power is perceived to be part of the solution to this problem. Despite North Korea's claim that it is developing its nuclear capabilities for the purpose of securing a stable supply of electric power, the international community's concerns that North Korea's primary goal is to develop nuclear weapons have not abated.

\section{The Geographical Advantage of the Korea}

As a junction of Eurasia, North Korea has a unique geopolitical advantage. Actually, with the global economy becoming increasingly more integrated, North Korea could overcome its economic weaknesses by seeking regional economic cooperation and take advantage of its geographic advantages. Conducting an economic open door policy would help it achieve great economic performance in future.

\section{The Geostrategic Position of the Korean Peninsula}

The challenge for the Korean Peninsula is not simply about how to improve bilateral relations between North Korea and South Korea. There are several major powers that have played historically significant roles on the Korean Peninsula. Why has it become the focus point of the major powers? The main reason is that the geostrategic value of the Korean Peninsula is considerable. Major Powers, such as the United States, Russia, China, Japan and others all have important geostrategic 
interests with regard to the Korean Peninsula. During World War II, the peninsula was a central battlefield intersecting the strategies of the opposing militaries. During the Cold War, the peninsula became the forefront of great power confrontation. Even today, the peninsula plays a significant role in the region. There are still large powers factoring the confrontation on the peninsula into their political calculations. Since the emergence of the North Korean nuclear crisis, the Korea Peninsula has increasingly become the hot spot of Northeast Asia.

For China, the Korean Peninsula is an import area in terms of the security of northeast China. Situated across the Yellow Sea, the west coast of the Korean Peninsula is very close to Beijing, China's political and economic center. Historically, China's national security was made vulnerable on account of the shifting circumstances on the Korean Peninsula. In previous wars, Japan always took the Korean Peninsula as a bridgehead for the invasion of the Asian continent. For Japan, the Korean Peninsula has significant geostrategic value. If the peninsula achieves reunification, the Japanese would likely lose its advantages to a unified Korea and face increasing economic pressure. For the United States, the Korean Peninsula was the forefront of its confrontation with the Soviet Union during the Cold War. Today, the Korean Peninsula is an important part of America's pivot to the Asia-Pacific. For Russia, the Korean Peninsula's location at the eastern end of the Asian continent links it to a series of islands on the outer edge of East Asia for Russia. The Korean Peninsula is therefore a significant factor for Russia securing its place in east. For example, the Tsushima Strait is an important waterway that connects Russia's major eastern center in Vladivostok and the Pacific. Intersecting the interests of major powers in the region, the Korean Peninsula is therefore of great geostrategic importance.

\section{The Geo-Economic Advantages of the Korean Peninsula}

Geographically, the Korea Peninsula is the economic center of Northeast Asia. It shares borders to the north with Russia and China and is surrounded by water on its other three sides. The East Sea/Sea of Japan is to the peninsula's east, the South Pacific is to its south, and China is across the waters to its west. The large countries surrounding the peninsula give it significant geo-economic importance. Russia, China, North Korea and South Korea are geopolitically connected. This provides good conditions for regional economic cooperation, particularly considering that these countries share huge potential economic interests.

The far eastern part of Russia has the most potential for development. To develop its far eastern region, Russia needs to strengthen cooperation with the countries of Northeast Asia, for which the Korean Peninsula will be very important. China's heavy industry base is in the northeast of China, only separated by a river from the Korean Peninsula. Northeast China's reform and opening up requires the cooperation of the Korean Peninsula. After the success of the reform and development of its southeast areas, China plans to develop northeastern provinces. This is highly depended on the cooperation of the Korea Peninsula. For example, Dandong, lying on the border between China and North Korea at the estuary of the Yalu River, has been designated as a major export production center for Liaoning 
Province. The Changjitu (Changchun-Jilin-Tumen) Regional Border Zone, which includes cross-border trade and economic cooperation with North Korea, also plays a great role in regional cooperation. On the other side, after the Cold War, China and South Korea established diplomatic relations. Both countries continue to strengthen their relations both politically and economically. After 2003, China maintains its largest trading partnership with South Korea, thereby gleaning large levels of investment from South Korea.

From the economic perspective, the Korean Peninsula has a very bright future as a hub of regional economic cooperation. The countries in this region are economically complementary to one another. Russia has abundant resources, especially energy resources, China has strong manufacturing capabilities, South Korea and Japan have advanced technology, and North Korea has high-quality human resources. These countries could therefore carry out carry out very effective economic cooperation within this region. All countries would benefit from such economic cooperation. From the geo-economic perspective, with global economic integration and regionalization, Northeast Asia has become the most dynamic region for economic development in the world. This trend will continue in the followings decades. However, due to the existence of the region's security and political obstacles in the region, regional economic cooperation is still falling behind its potential, which not only blocks neighboring countries' economic development, but also hinders regional economic integration. South Korea Unification Minister Yu Woo-ik recently stated that it is time for North Korea to choose to change. If North Korea makes the right choice, the South Korean government and people will provide whatever help North Korea requires for its economic development (Yu Woo-ik 2012).

\section{The Natural Conditions of North Korea's Economic Development}

With its geographic location, North Korea is the most crucial country for realizing the full potential of regional economic cooperation. However, despite its crucial geographic advantage, North Korea also faces disadvantages and shortcomings. Feeding the people has always been the foremost priority of Korean governments. North Korea has faced devastating periods of starvation in its territory. North Korea's perennial food shortage is not coincidental. Although North Korea's land size is about $120,000 \mathrm{~km}^{2}$, but around $70 \%$ of North Korea's territory is mountainous, only $18 \%$ of the land is arable, approximately 1.2 acres per person, which is one of the lowest in the world. Furthermore, due its climate, North Korea can only crop grain for one season per year. North Korea is also a natural disasterprone country. There are large or small floods almost every summer. Droughts occur very often in the autumn and typhoons occur in spring. North Korea's energy shortage reduces its capacity for disaster relief, making North Korean agriculture particularly vulnerable. Due to a lack of sufficient fertilizer, production facilities, agricultural machinery, and irrigation, North Korean food shortages become very serious emergencies. It is only through regional cooperation that North Korea could take full advantage of the Korean Peninsula's geographic location and achieve economic development. 
On the other hand, North Korea also has relatively abundant natural resources. These resources include sizable deposits of coal, minerals, and nonferrous metals. The mineral reserves with economic development value account for $80 \%$ of North Korea's land. There are approximately 200 kinds of minerals in North Korea. Anju and Pyongyang are North Korea's two largest anthracite coalfields. Pyongan-do holds a concentration gold-mineral fields within North Korea. North Korea has the largest magnetite and tungsten reserves, which account for 40-50\% of global reserves, respectively. The Korean Peninsula has world famous graphite reserves. Furthermore, North Korea boasts of its forests and abundant water resources. The Yalu, Tumen, Hanjiang, and Taedong river systems form an abundant source of power with hydropower stations that produce approximately 10 million kilowatts. The abundance of coal and water resources has allowed North Korea to construct a well-developed electrical power network. North Korea's preeminence as an energy producer began during the time of the Japanese occupation time with the Supung Hydroelectric Plant, located in the northwest. For a long time, its plant was the largest of its kind in Asia. North Korea supplied more than $90 \%$ of the electricity within the Korean Peninsula before the peninsula's division. In addition, North Korea's human resources are well developed. North Korea now has over 300 universities of various types and levels with high quality research departments. North Korea's abundance of underground resources has attracted growing interest from international investors, including from Europe and Japan (Matsumura 2008). Therefore, by opening up, North Korea could easily receive outside investment.

\section{Obstacles Faced by the North Korean Economy}

North Korea is in a geographically advantageous situation for regional economic cooperation. However, in the long-term, its deteriorating international relations are driving it into becoming an even more closed state. This is hindering North Korea's economic development the advancement of regional economic cooperation and integration in Northeast Asia. Security concerns are the most significant obstacles to North Korea taking steps to pursue opening and reform in its economic system.

The International Environment for Encouraging North Korea's Economic Reform is not Optimistic

Since 2000, North Korea's strategic focus has shifted to economic development but it has been unable to channel its resources into such development. Considering its geographic conditions, North Korea can only pursue improvements to its economy by exploiting its geographic advantages. However, in the face of enormous pressure from the powerful ROK-US Alliance and South Korea's advanced economic development, North Korea is unwilling to fully open its doors. This is because North Korean leadership believes that once North Korea begins to pursue opening up and reform policies it will be very hard for North Korea to resist South Korea's influence, which may further undermine the stability and security of the North Korean regime. Under these circumstances, North Korea is particularly concerned 
with the possibility of being absorbed by South Korea, for which reason North Korea will continue to pursue its military-first policy in the foreseeable future. This means that the heavy defense burden will continue to stand in the way of North Korea's national economic development.

\section{Economic Sanctions will Keep North Korea Closed}

There are large differences among interested countries on how to deal with the North Korean nuclear issue. When North Korea violated United Nations resolutions, the international community increased pressure on North Korea. Some countries, such as the United States and Japan, insisted on strong responses to North Korea's behavior, including tough economic sanctions. Therefore, North Korea has often accused the United States of obstructing its economic development. Other countries, such as China, believe that sanctions on North Korea may hurt the North Korean economy, affect the North Korean people's livelihood, and cause North Korea to become even more closed off.

\section{Fluctuating Policy and Lack of International Coordination vis-à-vis North Korea}

Although the both North Korea and South Korea have yearned for reunification for a long time and all Koreans believe that it is only a matter of time before North Korea and South Korea reach the goal of reunification. However, Korea's historical background is very complicated (Hui 2010). There is a significant gap between the two countries on some specific issues, including what approach to adopt and what process to achieve reunification. Historically, different reunification policies have been adopted by South Korean governments, including military reunification in the early days, the "Sunshine Policy" during South Korean President Kim Dae-jung's administration, the "Peace and Prosperity" policy during the Roh Moo-hyun period, and the Lee Myung-bak administration's policy of encouraging North Korea to abandon its nuclear program and open up. Although these policies were based on the international and South Korean domestic situations, the fluctuations in policy have made North Korea and South Korea's bilateral relations very fragile. In fact, the challenges faced by the Korean Peninsula have deep historical backgrounds. In dealing with specific issues, we should take into account these complex historical backgrounds when considering future developments on the Korean Peninsula.

\section{Economic Development of the Korean Peninsula and Economic Cooperation}

International Cooperation: the only Path for North Korean Economic Development

Because of its natural geographic conditions, North Korean's economic development must rely on the international market. As a small country, it is very hard for North Korea to establish a whole industrial system by itself, let alone a "selfsufficiency" economy that produces all of its own products. Small countries and 
island economies are highly depended on world trade and the international market. It cannot achieve of economies of scale, making its industrial products less competitive in the international market. Therefore, the only way for North Korea to advance its economic development is to be a part of the industrial chain in the global economic system. For these countries, international trade is essential for stimulating demand and promoting economic development. If such countries can effectively participate within the international system according to their advantages, their economic development will be much faster and more successful.

During the period where North Korea traded within the socialist camp under the Soviet Union, North Korea's food output reached 800 pounds per capita and an annual income of USD 900 per capita. At that time North Korea was quite a rich country. This changed after the collapse of the Soviet Union. In 1995, North Korea's store of food products dropped to only 3.5 million tons, a decrease of more than $65 \%$. Ten years after the collapse of Soviet Union, North Korea had fallen from a food-export country to country suffering severe famines. This is because after the collapse of the Soviet Union, North Korea's international trade was suddenly cut off from the outside world. North Korea's economic policy continued to focus on heavy industry. This policy, coupled with economic difficulties, resulted in a poor record for North Korea's exports, chronic trade deficits, and sizable foreign debt. Shortages of foreign exchange in the 1990s resulted in North Korea's energy import supply rapidly declining, which was a major factor behind North Korea's economic recession. Due to the shortage of energy, many factories were closed and North Korea's agricultural modernization was set back. For the reasons mentioned above, North Korea's economy suffered a deep slump during the 1990s that left North Korea far behind its rival, South Korea, which had become a world-class economic powerhouse.

\section{North Korean Explorations of Paths to Economic Development}

During the last decade, North Korea has suffered food shortages of 2-4 million tons out of its normal demand for 6.5 million tons per year. North Korea's need for humanitarian aid from the international community began in 1995. At the same time, due to a lack of electricity and raw materials, North Korea also struggled with a low operation rate from its factories. By 1996, production rates in industry and construction had dropped to one-third of what they had been in 1993. Other North Korean economic challenges include a lack of hard currency, energy shortages, and a lack of daily commodities. Under this situation North Korea began to commit itself to economic development reforms.

Although North Korean officials do not recognize the reform and opening up policy, the fact is that North Korea has begun exploring the road to economic development. While he was alive, Kim Jong-il, attempted to conduct economic reform in the hope of promoting North Korea's economic development by learning from the experiences of China. The range of locations that Kim Jong-il visited while traveling through China were very broad. They included supermarkets, businesses, economic development zones, and urban construction sites. This demonstrates that Kim Jong-il had a strong interest in China's socialist market economy. From 2010, 
Kim Jong-il visited China numerous times and was each time accompanied by Kim Jong-un. Many people expected that the visits were a sign that North Korea would embark on Chinese-style economic reforms. The framework for North Korea's present attempts at economic development was determined by Kim Jong-il while he was alive. According to the guidelines established by Kim Jong-il, North Korea will open the door leading to it becoming a "mighty and prosperous nation" by 2012. These guidelines include many economic and social indicators, all of which the North Korean leadership are expected to meet.

North Korea's infrastructure is very old, making it difficult for North Korea to develop its economy by itself. It therefore needs substantial funds from external sources. China and South Korea could become the necessary sources of support for North Korea's economic reforms in future. Because of its friendship with North Korea, China has a responsibility to provide the support necessary for North Korea's economic development and reform. China believes that, through economic development, North Korea will become relatively more responsible for the peace and development of the Korean Peninsula. Otherwise, a collapse in the North Korean economy would bring huge risks and long-term volatility and instability to the Korean Peninsula and the rest of Northeast Asia. In fact, China has provided a great deal of assistance to North Korea, including reconstruction of infrastructure, training for North Korean technical and management personnel, and encouraging North Korea to join international economic organizations. Although North Korea cannot completely copy China as a model for economic development, China's experience can give some reference to North Korea's economic development.

\section{North Korea's Economic Reforms}

It is important to note that North Korea has already undertaken a number of substantive initiatives to expand its international economic cooperation. The North Korean government repeatedly announced that it would establish friendly trade relations and seek economic cooperation with all capitalist countries that respect North Korea's sovereignty.

North Korea has been attempting to expand its foreign economic and trade cooperation relations to attract foreign investment since the 1980s. In 1984, the DPRK Supreme People's Assembly passed a joint venture law to allow foreign investment in enterprises or cooperative joint ventures in North Korea. Since then, North Korea has formulated the Foreign Investment Law, the Foreign-Owned Enterprise Law, the Cooperation law, the Alien Income Tax Act, and the Foreign Exchange Management Act. North Korea has thereby gradually improved its domestic conditions for foreign investment. Today, many outward-looking joint ventures and cooperative enterprises have settled in North Korea. Such companies range in activities from finance, communications, computers, machinery, household goods and hotels. Some joint ventures have been successfully established in special economic development zones. To date, North Korea has established diplomatic relations with the European Union and established economic trade relations with more than 100 countries and regions around the world. Since Kim Jung-un took power in North Korea, there have been a number of interesting signs of domestic 
changes taking place, including the broadcasting of famous Disney characters on North Korean state-run television (Fackler 2012).

Economic reforms in North Korea began being introduced by the North Korean government in 2002. On July 1, 2002, North Korea launched a number of comprehensive economic reforms, In terms of financial reform, the North Korean government allowed the supply and demand system to be based on fixed prices instead of a coupon system for rations. For currency value depreciation, the government offered export incentives to domestic firms and depreciated the value of the North Korean Won from 2.2 to 1 US dollar to 150 to 1 US dollar. This step helped the government to attract foreign investors. For the decentralization of economic decision-making, the North Korean government reduced the level of subsidies and allowed local offices to take managerial decisions for the agricultural and industrial sectors instead of the central government. For the formation of Special Economic Zones, the government of North Korea began forming industrial and administrative zones that could pave the way for foreign investment. The North Korean people were permitted to own property, start businesses, sell products and services, accumulate and invest capital, spend money in open markets, take out mortgages to buy a house, and thereby come to expect that by working hard they could enjoy a good standard of living.

\section{Promoting Economic Cooperation on the Korean Peninsula}

Seeking Political Consensus through Economic Cooperation

Although many efforts have been made by the international community, the fundamental divisions on the Korean Peninsula have not been altered in 60 years. Following the failure of South Korea's "Sunshine Policy," South Korean's frustration with North Korea increased dramatically. Although the situation is hard to resolved, the situation on the Korean Peninsula can only be resolved through engagement and cooperation. Economic cooperation will increase mutual trust between North Korea and South Korea. Previously, efforts to solve the peninsula's challenges mostly concentrated on military or political means, leaving economic solutions as subordinate possibilities. However, to resolve the issues on the Korean Peninsula, breakthroughs are more likely to be achieved through economic cooperation.

Economic development is an important goal of North Korea's new leadership. Economic cooperation is also a common interest of interested countries, such as China, the United States, and Japan. Through domestic economic development, North Korea will become more confident in the reform of its economic system. Through economic cooperation, North Korea will expand personnel exchanges and communications with other countries, which will thereby narrow the economic and cultural gap between the two Koreas. In this instance, economic cooperation is the more realistic and operationally feasible means of advancing cooperation on the Korean Peninsula. The international community should help in guiding North Korea to smoothly and gradually shift its focus to further economic development, which 
will permit North Korea to shift its focus from "military-first" to "economy-first." This would lay a strong foundation for the future peace, stability, and eventual unification of the Korean Peninsula.

\section{South Korea's Economy and International Cooperation}

Historically, South Korea made several attempts to improve its relations with North Korea, pursuing policies of engagement and cooperation to bring the two sides closer together. In recent decades, South Korea's economic development has been a story of impressive growth and transformation. For future economic cooperation and development, South Korea should send more signs of goodwill to North Korea. South Korea is now far ahead of its neighbor to the north. South Korea experienced the world-famous "Miracle on the Han River," and has become an advanced industrialized country. South Korea's economy has grown 400-fold and its GNI currently stands at over USD 1.2 trillion. Per capita income in South Korea increased from the beginning of the 1960s with less than USD 100 to reach USD 20,000 in 2007. South Korea has also built leading global high-tech and heavy industries, including mobile phones, semi-conductors, LCD TVs, automobiles, steelmaking and ship-building. South Korea is the world's eighth largest trading nation. In 2012, South Korea's economy is expected to stay steady but its growth rate may go down to $3.6 \%$. South Korea has extensive international contacts throughout the world and maintained especially strong economic relations with developed Western countries. South Korea should therefore work with the international community, and most especially with China, to strengthen economic cooperation and assistance to North Korea to diminish North Korean suspicions. Through international co-ordination, a mechanism for economic cooperation might eventually be formed that could lead to the enhancement of mutual trust, ease the situation on the Korea Peninsula, and eventually lead to the establishment of a collective security mechanism in Northeast Asia.

South Korea and North Korea have significant economic complementarity. North Korea has cheap labor and abundant natural resources. In combination with South Korea's abundant capital, advanced technology and equipment, both sides could glean tremendous economic benefits. North Korea has already shown some recent signs that it is willing to make changes. South Korean policy should also change to facilitate dialogue and a policy of engagement toward North Korea. Cao Donghao, a professor from Ewha Womans University in South Korea, proposed that South Korea should share its own experiences in economic development with North Korea so that North Korea may improve its economic competitiveness in the international community. He also proposed that South Korea should negotiate the joint development of an Economic Zone project around the Chinese and North Korean border (Zheng and Li 2012).

\section{Resolutions to Issues Faced by the Korean Peninsula Will Take Time}

"Rome was not built in a day". Considering the complex historical and political backgrounds of the issues on the Korean Peninsula, any final resolution would be 
the result of a long-term process. Taking into account the decision-making behind North Korea's own policies, it is necessary for the international community to maintain stable and continuous policies in order to avoid any cause for anxiousness amidst the North Korean leadership. Given the complex international nature of the issues facing the Korean Peninsula, resolutions of these issues will require efforts from all interested parties. As the South Korean newspaper Chosun Daily argued, North Korea cannot conduct fundamental economic development without an improved external environment (The Chosunlbo 2012).

Even within South Korea here are many different views on how reunification of the Korean Peninsula might be achieved. With South Korea's various political forces and developed democratic politics, reunification is an issue on which it is difficult to attain broad political consensus. Achieving the necessary policy adjustments takes time. Peace and unification on the Korean Peninsula cannot be achieved swiftly. Taking steps to improve North-South bilateral relations and avoiding military conflict are ongoing short-term concerns. In the medium-term, the international community needs to promote bilateral economic cooperation between the two Koreas in order to achieve the long-term goals of the denuclearization and eventual reunification of the Korean Peninsula.

\section{Promoting an International Environment for North Korea's Reform and Opening}

To consider further economic reform and development, the Korea Peninsula requires a peaceful international environment, including in terms of international politics, economics and security. In order to promote the reform and opening up of the North Korean economy, it is necessary to minimize the political pressure on North Korea. If North Korea does not violate the Charter of the United Nations, the international community should relieve the pressure on North Korea. The international community should especially attempt to avoid using economic sanctions instead of political solutions. To relieve North Korea's humanitarian crises, the international community also needs to give North Korea financial assistance. North Korea recognizes the importance of the international environment for its economic development and continuously attempts to overcome outside opposition and attract overseas investment.

It is important to note that long-term expectations among the international community should be based on eventually being able to invite North Korea to fully participate in the global economy. Guiding North Korea's continued economic integration is the responsibility of the international community. A key obstacle to overcome is the lack of trust between North Korea, South Korea, the United States, and Japan. Although economic cooperation and economic integration will not immediately lead to a resolution of the North Korean nuclear issue, it is only after North Korea achieves economic growth that progress can be made on the complete and irreversible denuclearization on Korean Peninsula. To this aim, contact made with North Korea should be conducted with open minds willing to encourage North Korea's economic development and participation in the international economic system. 
In conclusion, because of the complex historical backgrounds and present circumstances of the issues facing the Korean Peninsula, resolutions of these issues must result from long-term processes. The promotion of peace and further development through economic cooperation is a more realistic and feasible means of bringing about effective resolutions. Promoting economic cooperation should not only the core task of North Korea, but also the common focus of interested countries. It should be noted that there are no insurmountable obstacles to Northeast Asia regional cooperation. Achieving economic cooperation in Northeast Asia may have to be the result of a long process, but, with the strengthening of Northeast Asian economic and trade relations, regional peace and stability will be improved (Dian-Jun 2009). Through North Korean economic development and international cooperation, an increase of mutual trust will be achieved that will gradually lead to political reconciliation. Currently, many Northeast Asian countries have recognized the importance of regional cooperation and intend to continue to promote further regional cooperation and integration. Economic cooperation on the Korean Peninsula will benefit the economic development of Northeast Asia and the rest of the world.

\section{References}

Chao X, Zhong Y, Tong XS (2006) Bu Hui Yi He Wei She Li Huan Qu Jing Ji Yuan Zhu, (朝鲜中央通讯社 : 不会以核威慑力换取经济援助), http://news.oeeee.com/a/20100219/848758.html

Dian-Jun BA (2009) Dong Bei Ya Qu Yu Jing Ji He Zuo De Zheng Zhi Huan Jing (巴殿君: 东北亚区域经济合作的政治愿景), Dong Bei Ya Lu Tan (东北亚论坛), 2009, 18(4):25-31

Fackler M (2012) On North Korean TV, a Dash of (Unapproved) Disney Magic, The New York times, July 9, 2012, http:/www.nytimes.com/2012/07/10/world/asia/kim-jong-un-appears-with-mickeymouse-and-other-disney-characters-on-north-korean-tv.html?ref=northkorea

Jinwook CHOI (2006) The North Korean Domestic Situation and its Impact on the Nuclear Crisis, Ritsumeikan Annual Review of International Studies, ISSN 1347-8214. vol. 5, pp 1-18

Matsumura M (2008) New geo-economic thinking on North Korea in Japan, Intern J Korean Unification Stud 17(2):79-108

Ma TH (2010) Reunification of Korea is a major security issue on the Korean Peninsula-A the North Korean perspective, ASIA PAPER October 2010, Institute for Security and Development Policy, Stockholm-Nacka, Sweden, www.isdp.eu

Nandu.com (南方都市报) (2010) Chao Xian: Ying Qian Ding He Ping Xie Ding; Mei Guo: Xian Zhong Fan Liu Fang Hui Tan; Han Guo Yi He Yao Da Jia Shang Liang. (朝鲜：应签订和平协定; 美国 : 先重返六方会谈 ; 韩国 : 议和要大家商量), http://gcontent.oeeee.com/d/73/ d736bb10d83a904a/Blog/391/b36164.html

The Chosunlbo (2012) Gen Ben Xing Gai Ge Cai Neng Jie Jue Bei Han Que Liang Wen Ti, The Chosunlbo, 2012.07.26, [社论]根本性改革才能解决北韩缺粮问题朝鲜日报), http://chinese.chosun.com/ site/data/html_dir/2012/07/26/20120726000014.html

Yu Woo-ik (2012) Zui Jin Chao Xian De Bian Hua Ke Neng Shi Zou Shang Zheng Lu De Ji Xiang (柳佑益 : 最近朝鲜的变化可能是走上正路的迹象), http://chinese.yonhapnews.co.kr/domestic/2012/07/ 26/0401000000ACK20120726002800881.HTML.

Zheng Y, Li Y (2012) Wei Shi Chao Xian Zai Guo Ji She Hui Ju You Jing Zheng Li, Hanguo Ying Dan Dang Qi Jing Ji Dao Shi De Zuo Yong (郑墉洙, 李圆珍: 为使朝鲜在国际社会具有竞争力, 韩国应担当起经济导师的作用,中央日报，韩国) Korea Joongang Daily, 2012.07.26, http://chinese.joins.com/gb/article.do?method=detail\&art_id=89515 